\title{
Change the number of water reservoirs in the selected cities of the Upper Silesian
}

\section{Agglomeration over the period 1993-2014}

\author{
Dominika Dąbrowska¹, Jan Dąbrowski² \\ ${ }^{1}$ Department of Hydrogeology and Engineering Geology, Faculty of Earth Sciences, University of Silesia, Będzińska Str. 60, 41-200 \\ Sosnowiec, Poland \\ 2Outokumpu Distribution Polska Sp. z o.o. ul. Toruńska 7, 41-300 Dąbrowa Górnicza, Poland \\ E-mail address (corresponding author): ddabrowska@us.edu.pl
}

\begin{abstract}
The Upper Silesian Agglomeration is the most industrialized area in Poland and one of the most in Europe. It is situated in the eastern part of the Upper Silesia and covers nearly $1500 \mathrm{~km}^{2}$. This region is highly diverse in terms of the spatial structure. There are lots of water reservoirs besides built-up areas and industrial facilities. Many of them have also significance for nature. Water reservoirs in the Upper Silesian Agglomeration function under anthropogenic conditions. Water reservoirs have a different size and the genesis. This kind of occurrence conditions influences the water reservoirs` state. There are mainly water reservoirs of anthropogenic character in a study area. A lot of water reservoirs are strictly connected with coal exploitation in this region. Unfortunately, the number of water reservoirs in the cities of the Upper Silesian Agglomeration has lately decreased. Reservoirs are eliminated as a result of changes in industry, progressive land development, changes in environmental conditions. In this paper we present the results of the number of water reservoirs analysis in Katowice, Sosnowiec and Chorzów over the period 1993-2014. Field studies and analysis of topographic maps show a decrease in the number of water reservoirs in this region by tens of percent.
\end{abstract}

KEY WORDS: Upper Silesia, water bodies, hydrography, anthropogenic lake district

\section{Introduction}

The Upper Silesian Agglomeration, which is located in the Silesian voivodeship, is considered to be most urbanized and industrialized areas of Central Europe. This metropolitan region consists of 19 neighboring cities and occupies about 1500 $\mathrm{km}^{2}$. The second largest city is Katowice (the capital of the Silesian voivodeship), occupying an area of $165 \mathrm{~km}^{2}$.

The rapid development of industry in the Upper Silesian Agglomeration had started in the beginning of the $19^{\text {th }}$ century as a result of the discovery of mineral deposits. Developing mining, metallurgy and other industries as well as increased urbanization resulted in irreversible changes in the spatial management, and thus transformation of the environment - the disappearance of forest areas and agricultural areas (DĄBROWSKA \&
SOŁTYSIAK, 2015a). Most of riverbeds were regulated and the valleys were transformed. A lot of wetlands were drained (DĄBROWSKA, 2014).

There are few natural water reservoirs in the Upper Silesian Agglomeration. In the majority there are artificial reservoirs. Some of them can take over the natural features during the succession process (SOŁTYSIAK \& DĄBROWSKA, 2014). Many anthropogenic reservoirs in this region have a complex origin, e.g. reservoirs in artificially created water-filled depressions or reservoirs located in the area of mining subsidence (RZĘTAŁA, 2008).

The most characteristic types of water reservoirs in the study area are: post-regulation, postexploitation, subsidence reservoirs, dam reservoirs, ponds and technological reservoirs (DĄBROWSKA \& SOŁTYSIAK, 2015b).

Water reservoirs in the Upper Silesian Agglomeration function in specific conditions. 
These conditions are connected with particular character of the course of limnic processes, stimulated eutrophication, higher than 10 water pH level (RZĘTAŁA, 2008). These conditions significantly reduce the quality of the water reservoirs too.

Fresh waters are one of the most threatened ecosystems in the world (RICCIARDI \& RASMUSSEN, 1999; RosSET ET AL., 2013). A very upsetting fact is that, unfortunately, the number of water reservoirs in the Upper Silesian Agglomeration is diminishing. Reservoirs are eliminated as a result of changes in industry - a lot of water reservoirs that were existing during the early capitalist economy were liquidated in the socialist economy because they do not satisfy production requirements (RZĘTAŁA ET AL., 2006), progressive land development, changes in environmental conditions, e.g the reason of excavation reservoirs elimination is that these water reservoirs were created as a result of mine operations and now they are treated as mining damage, which should be backfilled.

The Upper Silesia Agglomeration is not isolated case. There is a big issue of reducing the surface of wetland habitats and the number of water reservoirs in Europe. In many European countries abolished $40-90 \%$ of these objects (OERTLI ET AL., 2002). The number of reservoirs, located mainly in the agricultural landscape, decreased by $78 \%$ since 1890 until 1960 in Wielkopolska Lowland (Poland), (STASIAK, 1991, following KANIECKI, 1991).

\section{Aim and research methodology}

Water reservoirs located in anthropogenic areas are a valuable part of the spatial structure. The role of water reservoirs is often neglected. Water reservoirs of the Upper Silesian Agglomeration fulfill many functions. Many of these objects are liquidated during drainage. Determination of the number of existing reservoirs will allow assessing the impact of the city and industry development trends on their state.

It was made an analysis of the number of existing and liquidated in years 1993-2014 water reservoirs in selected cities of the Upper Silesian Agglomeration - Katowice, Sosnowiec and Chorzów. It were taken into account the data from 1980s on the basis of topographic maps at a scale of 1:10 000 (MAPA TOPOGRAFICZNA, 1993). The current state of the water reservoirs was determined on the basis of the data presented in websites www.mapserver.um.katowice.pl and www.geoportal.gov.pl also based on the field research.
It were determined three classes of water reservoirs in the case of Katowice (existing reservoirs, drained reservoirs and liquidated reservoirs) and two classes in the case of Sosnowiec and Chorzów (existing and liquidated ones).

\section{Characteristics of study area}

Katowice $\left(165 \mathrm{~km}^{2}\right)$ is the largest city of the Silesian voivodeship, in which mining areas represent $84 \%$ of the surface. Urban areas cover about half area of the city (of which $12 \%$ are residential buildings located primarily in the northern and western parts of Katowice). Communication areas occupying about $10 \%$ of the city surface and they are concentrated in the city center. Green areas represent around $4 \%$, and wastelands occupy less than $2 \%$ of city surface. The dominant elements are woodlands - more than $40 \%$. They are located primarily in the southeastern part of Katowice (Fig. 1).

Katowice is located in the left hand part of the Vistula (over $80 \%$ ) and the right-hand part of the Oder (almost 20\%). The length of the rivers flowing through the city is equal to $107 \mathrm{~km}$, of which $71 \mathrm{~km}$ are part of the Mleczna and Kłodnica watershed. Within the limits of the city Kłodnica and Ślepiotka river are formed (STudium ..., 2012).

There are two nature reserves in Katowice Murckowski Forest and Ochojec and ecological areas - ponds in the Tysiąclecie housing estate, the Grunfeld pond and the previously mentioned Kłodnica river sources (RAKOWSKI ET AL., 2007).

The spatial structure of Sosnowiec $\left(91.1 \mathrm{~km}^{2}\right)$ is dominated by built-up areas, which account for about $42 \%$ of the total area. Build-up areas occupy a large region of the central and western part of Sosnowiec. Farmland lands represent more than $22 \%$ of the city surface, and the third are forest lands - almost $22 \%$ of the area, especially located in the southern and eastern part (DĄBROWSKA, 2014). The spatial structure of Sosnowiec is shown in Fig. 2.

Sosnowiec is located at the confluence of two major rivers - the Czarna Przemsza and Biała Przemsza. The other rivers flowing through the city include: Bobrek river, Brynica river, Mortimerowski stream, Zagórski and Jamki streams. All of them have been regulated.

The area of Chorzów is equal to $33.5 \mathrm{~km}^{2}$ and it is a typical city of the Upper Silesian Agglomeration (www.chorzow.eu). There is a closely built-up city center and peripheral areas with less development in the spatial structure. Built up areas occupy more than $46 \%$. Undeveloped areas are situated near the borders (CZAJA \& RZĘTAEA, 
1998). In the north, near the border with Bytom, a landscape area called the Żabie Doły (Frog Pits), is located. In the north-eastern part of Chorzow agricultural lands (about 8\%) are located. In the central - eastern part of the city, the Silesian Park occurs, at the area of $6 \mathrm{~km}^{2}$ (SOŁTYSIAK \& DĄBROWSKA, 2015). In the southern part of the city there is a forest complex (Fig. 3). Forest lands represent $7 \%$ of the city area.

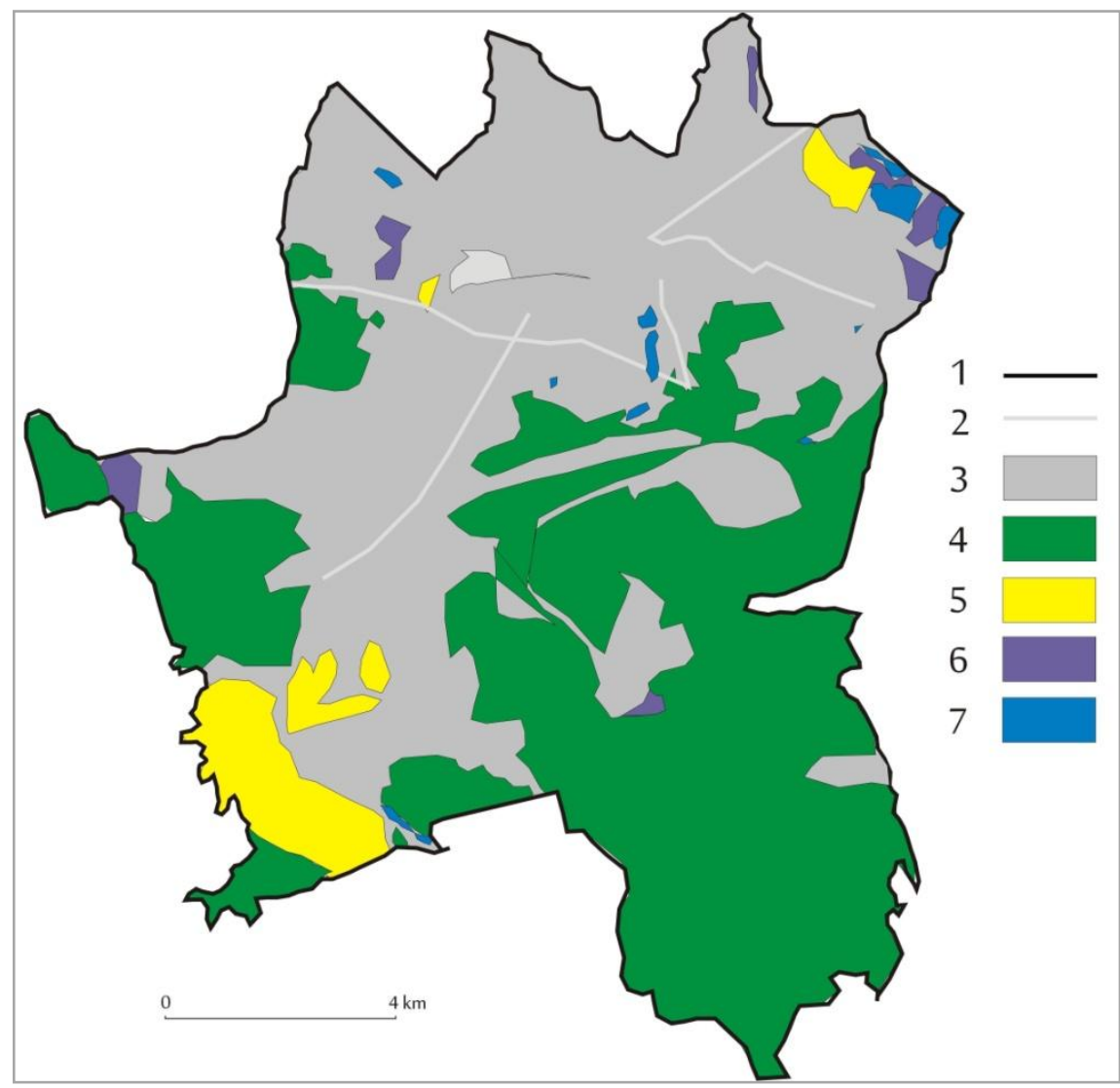

Fig.1. Spatial structure of Katowice (based on Studium..., 2012)

1 - boundary of the city, 2 - roads and communication area, 3 - built-up area, 4 - forest land, 5 - agricultural land, 6 - wasteland, 7 - land under water

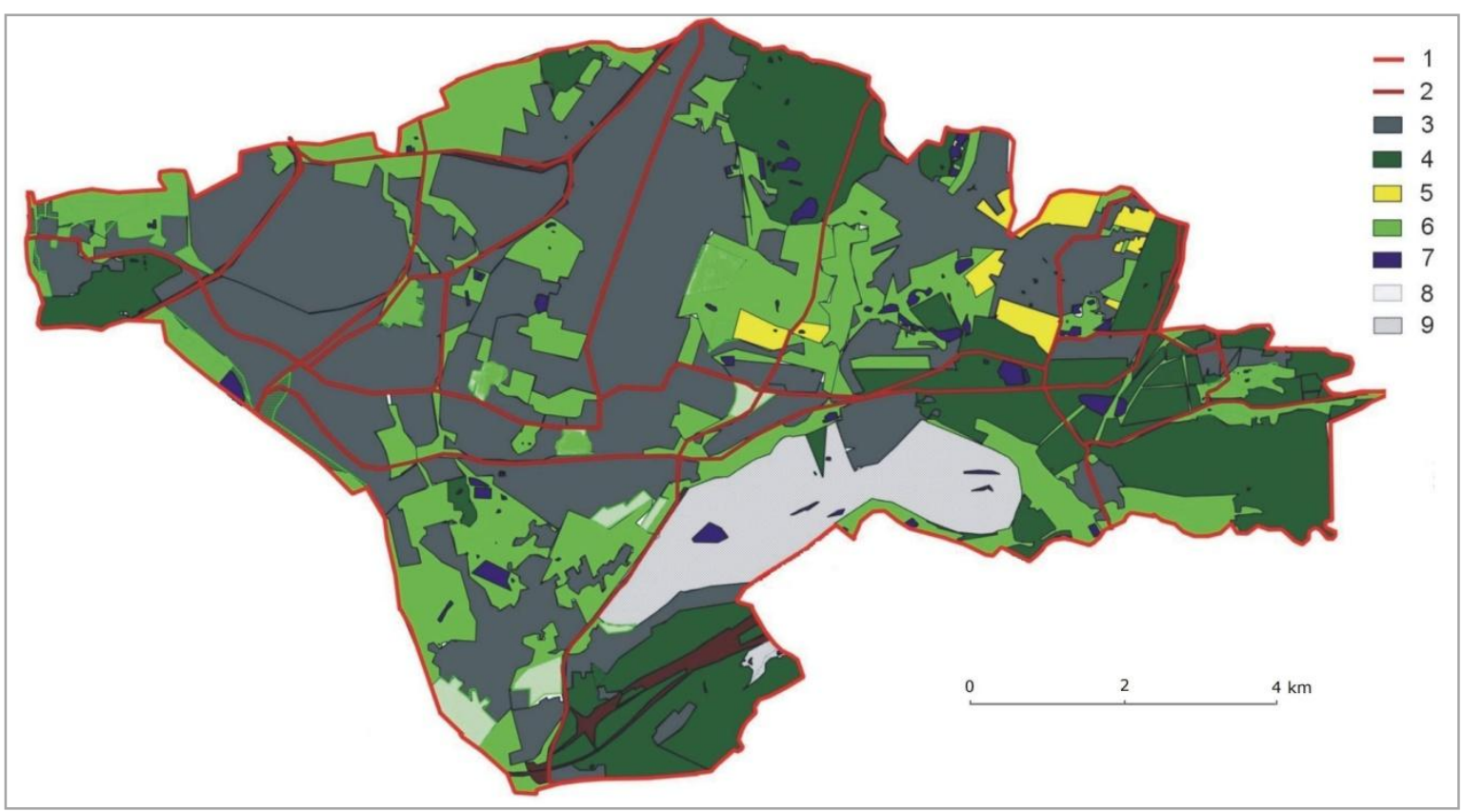

Fig. 2. Spatial structure of Sosnowiec (based on Plan zagospodarowania ..., 2013)

1 - boundary of the city, 2 - roads and communication area, 3 - built-up area, 4 - forest land, 5 - agricultural land, 6 - green land and wasteland, 7 - land under water, 8 - sandpit, 9 - heap 


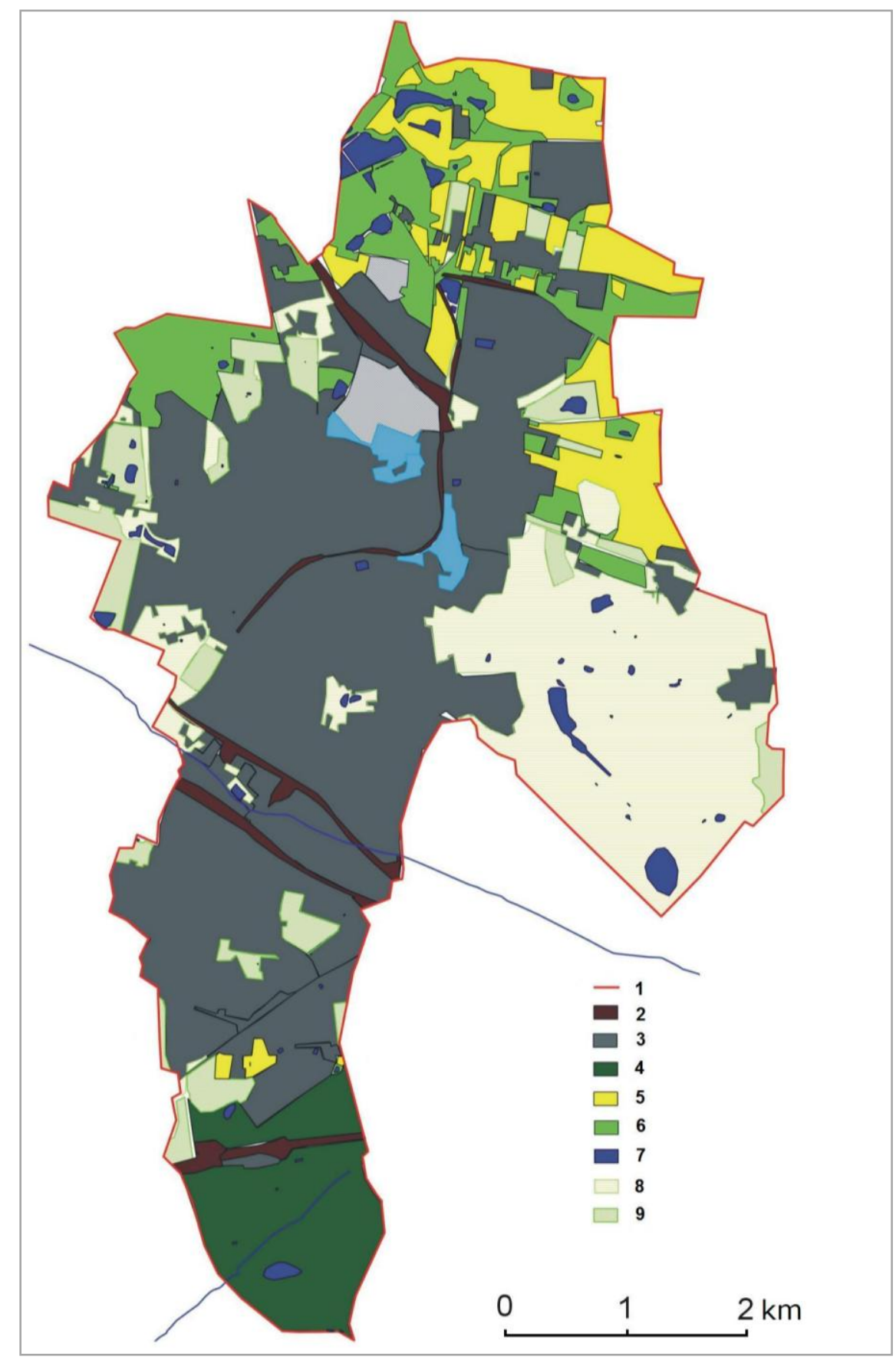

Fig. 3. Spatial structure of Chorzów (based on Sołtysiak, Dąbrowska, 2015)

1 - boundary of the city, 2 - roads and communication area, 3 - built-up area, 4 - forest land, 5 - agricultural land,

6 - wasteland, 7 - land under water, 8 - heap, 9 - allotment garden

\section{Water reservoirs in described cities}

Numerous water reservoirs of different size and different origins are the characteristic element of the landscape in the Upper Silesian agglomeration. Many of them are small reservoirs (less than $1 \mathrm{ha}$ ). There are three main types of reservoirs in these cities: slump reservoirs, excavation reservoirs and industrial reservoirs (CZAJA, 1994; SOŁTYSIAK \& DĄBROWSKA, 2014).

Subsidence reservoirs were created in places where an underground exploitation of deposits was conducting. A characteristic feature of these objects is shallow depth (MACHOWSKI, 2010), e.g. the Mleczna reservoir in Katowice.

Excavation reservoirs were created in areas of open exploit the existing mineral deposits. This system of exploitation is the most dangerous for the environment. Another factor influences the localization of excavation water reservoirs is the site and the extent of the deposits occurrence (MolEnda, 2011). These objects are characterized by a specific morphometry associated with the pit shape. Water reservoirs created in this way are 
one of the simplest forms of the land remediation, e.g. the Gliniak reservoir in Katowice, the Stawiki reservoir in Sosnowiec or the Żabie Doły in Chorzów. Water reservoirs formed as a result of the Quaternary sands exploitation dominant are. There are less frequently reservoirs caused by the coal exploitation.

Technological reservoirs represent a significant group of reservoirs in the study area. They can perform the socio-economic functions, e.g. the fire, municipal (next to the wastewater treatment plants) or act as a sediment reservoir (MOLENDA, 2006). They can also perform functions of natural reservoirs but many of industrial reservoirs, due to vertical walls are traps for animals.

The primary functions of water reservoirs in the study area are recreation and the landscape aspect. Water reservoirs located next to the parks or bicycle paths have the recreational function, e.g. the Bagry reservoir in Sosnowiec. The attractiveness of these reservoirs is caused by the water quality, the land-use environment and the availability for users (DĄBROWSKA \& SOŁTYSIAK, 2015a). Water reservoirs play also the important role in the environment and they are used to preserve a biodiversity (SCHEFFER \& VAN NES, 2007).

\section{Results}

Technological reservoirs are mainly concentrated in the central part of all cities, within the presence of industrial plants. Other water reservoirs are concentrated in the east of Sosnowiec in the northern and eastern part of Chorzów and in the western part of Katowice.

Due to the difficulties in determining the current status of all water reservoirs only on the basis of the cartographic material, a group required to verification water reservoirs was determined. This issue was related mainly to Katowice. More than 50 water reservoirs were subjected to the field verification.

After the status of reservoirs verifying the number of reservoirs in Katowice is equal to: 139 existing water reservoirs (without technological reservoirs), 18 drained water reservoirs and 65 liquidated water reservoirs (Fig. 4).

There are 88 existing water reservoirs in Sosnowiec (Fig. 5) and 107 water reservoirs in Chorzów (Fig. 6) and respectively 50 and 21 were liquidated during last twenty years.

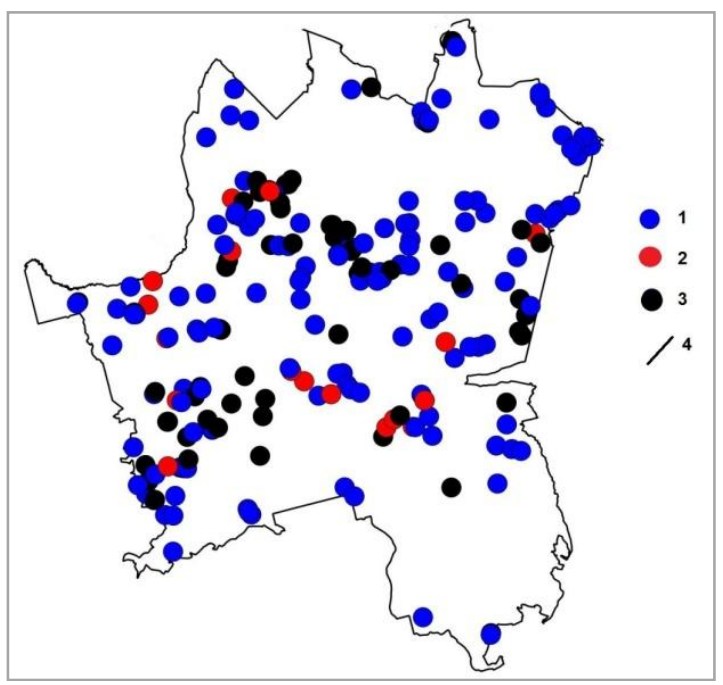

Fig. 4. Water reservoirs in Katowice

1 - existing reservoirs, 2 - drained reservoirs, 3 - liquidated reservoirs, 4 - boundary of the city

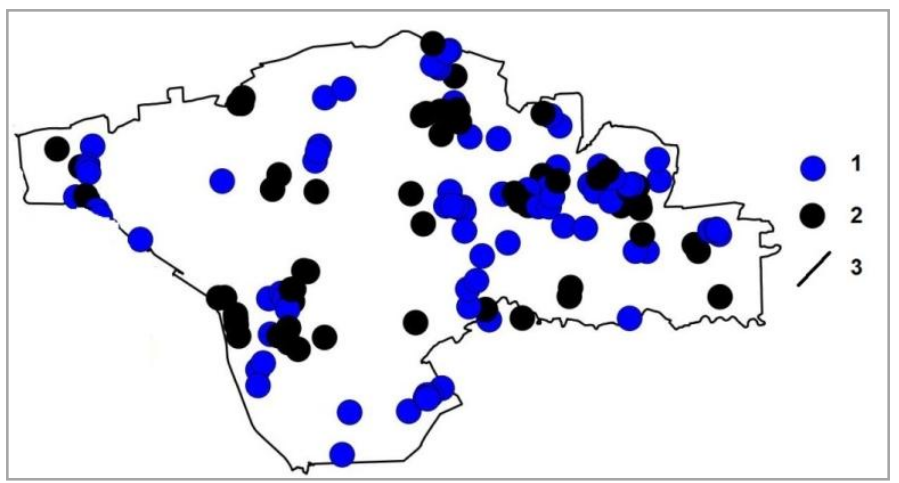

Fig. 5. Water reservoirs in Sosnowiec

1 - existing reservoirs, 2 - liquidated reservoirs, 3 - boundary of the city 


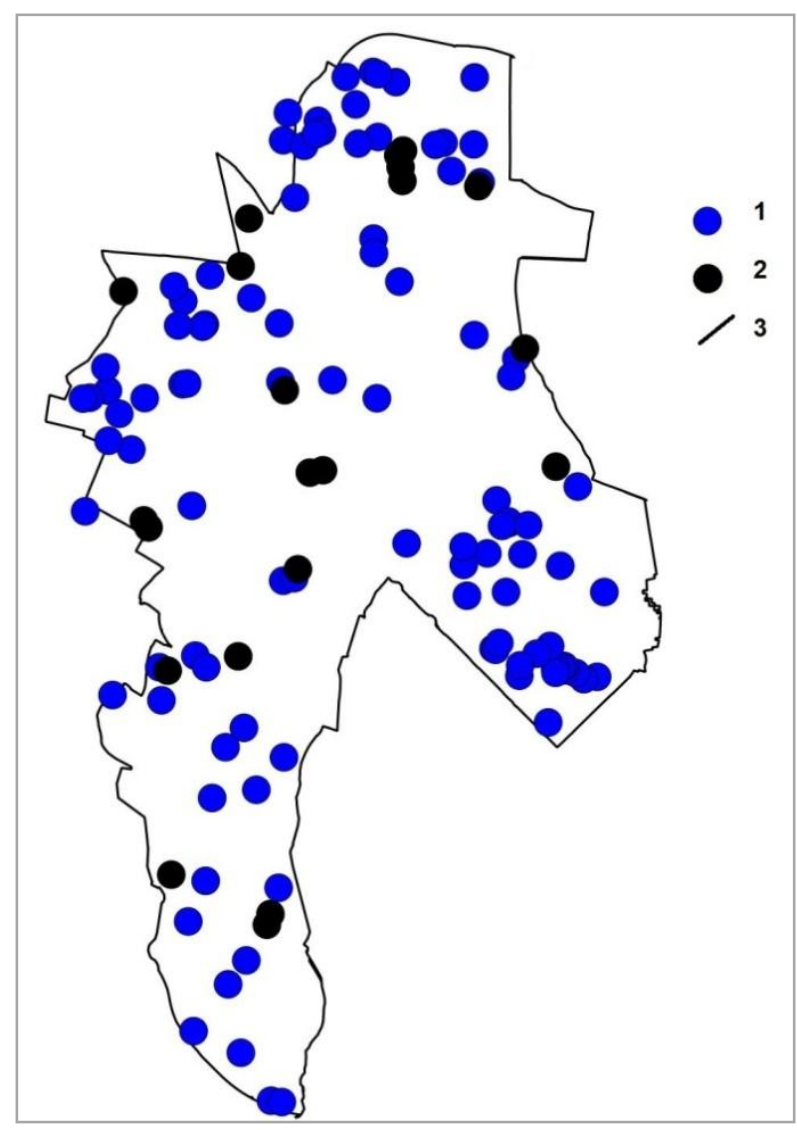

Fig. 6. Water reservoirs in Chorzów

1 - existing reservoirs, 2 - liquidated reservoirs, 3 boundary of the city

\section{Summary}

Water reservoirs are characteristic elements of the Upper Silesian Agglomeration spatial structure. Main uses of water reservoirs include aesthetic recreational uses, recreational fisheries or industrial and cooling water supply. Very important for biodiversity are small ones (below $1 \mathrm{ha}$ ). Frequently, this kind of reservoirs are the most important elements of urban areas. They have got unique natural and aesthetic values and they are habitat of many species of protected plants and animals (OŻGO, 2010). There is the highest species richness in aquatic ecosystems. The most important are reservoirs of natural features. Their natural importance increases with the distance from development areas and roads. Technological reservoirs, situated at closed and built-up areas, generally does not matter for biodiversity.

Specific changes in the way of land use refer to the many small water reservoirs. Many of them, which were originally treated as wastelands are now valuable natural habitats subject to the legal protection as ecological areas or Natura 2000 areas.

The very upsetting fact is that, the number of reservoirs in the Upper Silesia Agglomeration is diminishing. Disappearance of water reservoirs and neighboring local ecosystems is characteristic for urban areas (SOŁTYSIAK \& DĄBROWSKA, 2014). An important factor is the elimination of reservoirs as a result of the progressive building of the area, development of industry and changes in environmental conditions. Over the research period of time, the number of water reservoirs in Katowice, Sosnowiec and Chorzów decreased by $30 \%$. Lots of these places were natural habitats for many groups of plants and animals.

It is, however, possible to create new reservoirs usually due to subsidence of land or as a result of intentional actions, but at the moment such increase in the number of subsidence reservoirs is small, because of the end-stage of mining activity.

\section{References}

Czaja S. 1994. Zmiany zagospodarowania przestrzennego i powierzchniowej sieci hydrograficznej na obszarze miasta Sosnowca w latach 1783-1985. Rocz. Sosnowiecki. Urząd Miejski, Sosnowiec: 84-88.

Czaja S., Rzętała M. 1998. Zmiany użytkowania terenu i sieci hydrograficznej w Chorzowie od XVIII wieku do czasów współczesnych. Zesz. Chorzowskie, Muzeum w Chorzowie, Chorzów.

Dąbrowska D. 2014. Ekosystemy wodne jako naturalne środowisko występowania płazów na przykładzie miasta Sosnowiec. II Studencka Konf. Herpetologiczna. Uniw. Wrocł., Wrocław.

Dąbrowska D., Sołtysiak M. 2015a. The impact of anthropogenic factors on the natural values of the water reservoirs in Sosnowiec. Environ. \& Socio-econ. St., 3, 1: 20-25.

Dąbrowska D., Sołtysiak M. 2015b. Zmiana liczby zbiorników wodnych w Katowicach w latach 1993-2014 - preliminary results. Acta Geogr. Silesiana, 18: 5-10.

Kaniecki, A. 1991. Problem odwodnienia Niziny Wielkopolskiej w ostatnich 200 latach a zmiany warunków wodnych. [in:] Ochrona i racjonalne użytkowanie zasobów wodnych na terenach rolniczych $w$ regionie wielkopolskim. Mat. Konf. Nauk. Poznań: 77-88.

Machowski R. 2010. Przemiany geosystemów zbiorników wodnych powstałych $w$ nieckach osiadania (na przykładzie Wyżyny Katowickiej). Uniw. Śląski, Katowice.

Mapa topograficzna 1:10 000, sheets: Będzin, Chorzów, Chorzów Batory, Czeladź, Dąbrowa Górnicza, Dąbrowa Górnicza Strzemieszyce, Jaworzno Os. Stałe, Katowice Panewniki, Katowice Ligota, Katowice Piotrowice, Mikołów Płd., Tychy, Katowice Śródmieście, Katowice Szopienice, Katowice Os. Paderewskiego, Katowice Giszowiec, Katowice Murcki, Mysłowice, Mysłowice Wesoła, Tychy Wartogłowiec, Lędziny, Piekary Śl.Brzozowice-Kamień, Ruda Śl.- Kochłowice, Siemianowice Śl., Sławków Niwa, Sosnowiec, Sosnowiec Klimontów, Sosnowiec Maczki, Świętochłowice, CODGIK, 1993.

Molenda T. 2006. Górnicze środowiska akwatyczne - obiekty obserwacji procesów hydrologiczno-biologicznych. Prace Nauk Inst. Górn. Politech. Wroct., Studia i Mat., 117: 239-250.

Molenda T. 2011. Natural and anthropogenic conditions of physical and chemical water changes in post-mining aquatic areas of Upper Silesian region and its neighbouring area. Univ. of Silesia. Katowice. 
Oertli B., Joye D.A., Castella E., Juge R., Cambin D., Lachavanne J.B. 2002. Does size matter? The relationship between pond area and biodiversity. Biol. Conserv., 104 (1): 59-70.

Ożgo M. 2010. Rola drobnych zbiorników wodnych w ochronie bioróżnorodności. Parki Narod. i Rezer. Przyr., Białowieża: 117-122.

Plan zagospodarowania przestrzennego Sosnowca. Urząd Miasta, Sosnowiec, 2013.

Rakowski G., Walczak M., Smogorzewska M. 2007. Rezerwaty przyrody w Polsce Południowej. Inst. Ochr. Środ., Warszawa.

Ricciardi A., Rasmussen J.B. 1999. Extinction rates of North American freshwater fauna. Conserv. Biol., 13: 1220-1222.

Rosset V., Simaika J.P., Arthaud F., Bornette G., Vallad D., Samways M.J., Oertli B. 2013. Comparative assessment of scoring methods to evaluate the conservation value of pond and small lake biodiversity. Aquatic Conser. Mar. Fresh. Ecosyst., 23: 23-36.

Rzętała M. 2008. Funkcjonowanie zbiorników wodnych oraz przebieg procesów limnicznych $w$ warunkach zróżnicowanej antropopresji na przykładzie region śląskiego. Uniw. Śląski, Katowice.

Rzętała M., Rahmonov O., Malik I., Oleś W., Pytel S. 2006. Study on use of artificial water reservoirs in Silesian Upland (southern Poland) as element of cultural landscape. Ekologia. Bratislava, 25, 1: 212-220.
Scheffer M., van Nes E. 2007. Shallow lakes theory revisited: various alternative regimes driven by climate, nutrients, depth and lake size. Hydrobiology Bull., 584.

Sołtysiak M., Dąbrowska D. 2014. Is there a space for amphibians in the area of Chorzów city and Sosnowiec city? Urban Fauna. Univ. of Sci. and Techn. in Bydgoszcz. Bydgoszcz: 161-168.

Sołtysiak M., Dąbrowska D. 2015. Small water reservoirs in the city. A case study of Chorzów. PhD Interdisciplinary J. Gdańsk Univ. of Technol., Gdańsk, 1: 27-36.

Stasiak P. 1991. Zanikanie małych zbiorników wodnych na Nizinie Wielkopolskiej na podstawie materiałów kartograficznych. Praca magist. Uniw. A. Mickiewicza w Poznaniu, Poznań.

Studium planu miejskiego Katowic. Biuro Rozwoju Region. Katowic, Katowice, 2012.

www.chorzow.eu

www.geoportal.gov.pl

www.mapserver.um.katowice.pl 